\title{
Publisher Correction to: BMC Plant Biology, Volume 20, supplement 1
}

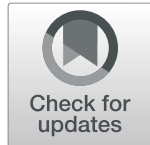

BMC Plant Biology

Supplement 1 published in Volume 20 of BMC Plant Biology contained several incorrect 'received dates' ${ }^{\prime}$. These errors were introduced during the production and publication process. In this correction article the incorrect and correct dates are published. The original articles [1-10] have been updated.

\begin{tabular}{|c|c|c|}
\hline Publication & $\begin{array}{l}\text { Original } \\
\text { (incorrect) } \\
\text { received date } \\
\end{array}$ & $\begin{array}{l}\text { Current } \\
\text { (correct) } \\
\text { received date }\end{array}$ \\
\hline $\begin{array}{l}\text { Genome-wide association study of } \\
\text { leaf rust resistance in Russian } \\
\text { spring wheat varieties }\end{array}$ & 29 January 2020 & $\begin{array}{l}12 \text { September } \\
2019\end{array}$ \\
\hline $\begin{array}{l}\text { Identification of polycomb } \\
\text { repressive complex } 1 \text { and } 2 \text { core } \\
\text { components in hexaploid bread } \\
\text { wheat. }\end{array}$ & 10 February 2020 & $\begin{array}{l}13 \text { September } \\
2019\end{array}$ \\
\hline $\begin{array}{l}\text { Molecular cytological analysis of } \\
\text { alien introgressions in common } \\
\text { wheat lines derived from the cross } \\
\text { of TRITICUM AESTIVUM with T. } \\
\text { kiharae. }\end{array}$ & 26 March 2020 & $\begin{array}{l}6 \text { September } \\
2019\end{array}$ \\
\hline $\begin{array}{l}\text { Dynamical climatic model for time } \\
\text { to flowering in Vigna radiata }\end{array}$ & 30 March 2020 & $\begin{array}{l}4 \text { September } \\
2019\end{array}$ \\
\hline $\begin{array}{l}\text { Key metabolites associated with } \\
\text { the onset of flowering of guar } \\
\text { genotypes (Cyamopsis } \\
\text { tetragonoloba (L.) Taub). }\end{array}$ & 19 May 2020 & $\begin{array}{l}9 \text { September } \\
2019\end{array}$ \\
\hline Genetic diversity of $S A D$ and $F A D$ & 28 May 2020 & 27 September \\
\hline
\end{tabular}

${ }^{1}$ The received date is when an article is submitted for peer review.

The original article can be found online at https://doi.org/10.1186/s12870020-02333-3; https://doi.org/10.1186/s12870-020-02384-6; https://doi.org/10. 1186/s12870-020-02407-2; https://doi.org/10.1186/s12870-020-02408-1; https://doi.org/10.1186/s12870-020-02498-x; https://doi.org/10.1186/s12870020-02499-w; https://doi.org/10.1186/s12870-020-02514-0; https://doi.org/10 1186/s12870-020-02536-8; https://doi.org/10.1186/s12870-020-02334-2; https://doi.org/10.1186/s12870-020-02579-x.

Correspondence: info@biomedcentral.com London, UK

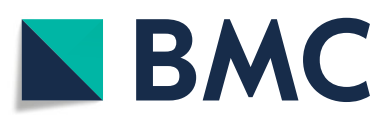

() The Author(s). 2021 Open Access This article is licensed under a Creative Commons Attribution 4.0 International License, which permits use, sharing, adaptation, distribution and reproduction in any medium or format, as long as you give appropriate credit to the original author(s) and the source, provide a link to the Creative Commons licence, and indicate if changes were made. The images or other third party material in this article are included in the article's Creative Commons licence, unless indicated otherwise in a credit line to the material. If material is not included in the article's Creative Commons licence and your intended use is not permitted by statutory regulation or exceeds the permitted use, you will need to obtain permission directly from the copyright holder. To view a copy of this licence, visit http://creativecommons.org/licenses/by/4.0/ The Creative Commons Public Domain Dedication waiver (http://creativecommons.org/publicdomain/zero/1.0/) applies to the data made available in this article, unless otherwise stated in a credit line to the data.
Published online: 15 January 2021

\section{References}

Leonova IN, Skolotneva ES, Salina EA. Genome-wide association study of leaf rust resistance in Russian spring wheat varieties. BMC Plant Biol. 2020; 20:135 https://doi.org/10.1186/s12870-020-02333-3.

2. Strejčková B, Čegan R, Pecinka A, et al. Identification of polycomb repressive complex 1 and 2 core components in hexaploid bread wheat. BMC Plant Biol. 2020;20:175 https://doi.org/10.1186/s12870-020-02384-6.

3. Orlovskaya O, Dubovets N, Solovey L, et al. Molecular cytological analysis of alien introgressions in common wheat lines derived from the cross of TRIT ICUM AESTIVUM with T. kiharae. BMC Plant Biol. 2020;20:201 https://doi.org/ 10.1186/s1 2870-020-02407-2

4. Kozlov K, Sokolkova A, Lee CR, et al. Dynamical climatic model for time to flowering in Vigna radiata. BMC Plant Biol. 2020;20:202 https://doi.org/10. 1186/s12870-020-02408-1.

Arkhimandritova S, Shavarda A, Potokina E. Key metabolites associated with the onset of flowering of guar genotypes (Cyamopsis tetragonoloba (L.)

\begin{tabular}{|c|c|c|}
\hline Publication & $\begin{array}{l}\text { Original } \\
\text { (incorrect) } \\
\text { received date }\end{array}$ & $\begin{array}{l}\text { Current } \\
\text { (correct) } \\
\text { received date }\end{array}$ \\
\hline $\begin{array}{l}\text { genes responsible for the fatty acid } \\
\text { composition in flax cultivars and } \\
\text { lines. }\end{array}$ & & 2019 \\
\hline $\begin{array}{l}\text { Effects of Rht } 17 \text { in combination } \\
\text { with } V r n-B 1 \text { and } P p d-D 1 \text { alleles on } \\
\text { agronomic traits in wheat in black } \\
\text { earth and non-black earth regions. }\end{array}$ & 15 June 2020 & $\begin{array}{l}4 \text { September } \\
2019\end{array}$ \\
\hline $\begin{array}{l}\text { Genetic variability of spelt factor } \\
\text { gene in Triticum and Aegilops } \\
\text { species. }\end{array}$ & 28 May 2020 & $\begin{array}{l}10 \text { September } \\
2019\end{array}$ \\
\hline $\begin{array}{l}\text { The mechanism of potato } \\
\text { resistance to Globodera } \\
\text { rostochiensis: comparison of root } \\
\text { transcriptomes of resistant and } \\
\text { susceptible Solanum phureja } \\
\text { genotypes. }\end{array}$ & 31 January 2020 & 3 October 2019 \\
\hline $\begin{array}{l}\text { Genome-wide association study in } \\
\text { accessions of the mini-core collec- } \\
\text { tion of mungbean (Vigna radiata) } \\
\text { from the World Vegetable Gene } \\
\text { Bank (Taiwan). }\end{array}$ & 30 April 2020 & $\begin{array}{l}13 \text { September } \\
2019\end{array}$ \\
\hline
\end{tabular}


Taub). BMC Plant Biol. 2020;20:291 https://doi.org/10.1186/s12870-02002498-X.

6. Dmitriev AA, Kezimana P, Rozhmina TA, et al. Genetic diversity of SAD and FAD genes responsible for the fatty acid composition in flax cultivars and lines. BMC Plant Biol. 2020;20:301 https://doi.org/10.1186/s12870-020-02499-w.

7. Kroupin PY, Karlov Gl, Bespalova LA, et al. Effects of Rht17 in combination with Vrn-B1 and Ppd-D1 alleles on agronomic traits in wheat in black earth and non-black earth regions. BMC Plant Biol. 2020;20:304 https://doi.org/10. 1186/s12870-020-02514-0.

8. Vavilova V, Konopatskaia I, Blinov A, et al. Genetic variability of spelt factor gene in Triticum and Aegilops species. BMC Plant Biol. 2020;20:310 https:// doi.org/10.1186/s12870-020-02536-8.

9. Kochetov AV, Egorova AA, Glagoleva AY, et al. The mechanism of potato resistance to Globodera rostochiensis: comparison of root transcriptomes of resistant and susceptible Solanum phureja genotypes. BMC Plant Biol. 2020; 20:350 https://doi.org/10.1186/s12870-020-02334-2.

10. Sokolkova A, Burlyaeva M, Valiannikova T, et al. Genome-wide association study in accessions of the mini-core collection of mungbean (Vigna radiata) from the World Vegetable Gene Bank (Taiwan). BMC Plant Biol. 2020;20:363 https://doi.org/10.1186/s12870-020-02579-x.

Ready to submit your research? Choose BMC and benefit from:

- fast, convenient online submission

- thorough peer review by experienced researchers in your field

- rapid publication on acceptance

- support for research data, including large and complex data types

- gold Open Access which fosters wider collaboration and increased citations

- maximum visibility for your research: over $100 \mathrm{M}$ website views per year

At BMC, research is always in progress.

Learn more biomedcentral.com/submissions 